\title{
Construction and Characterization of Insect Cell-Derived Influenza VLP: Cell Binding, Fusion, and EGFP Incorporation
}

\author{
Yi-Shin Pan, ${ }^{1}$ Hung-Ju Wei, ${ }^{2}$ Chung-Chieh Chang, ${ }^{1}$ Chung-Hung Lin, ${ }^{1}$ Ting-Shyang Wei, ${ }^{1}$ \\ Suh-Chin Wu, ${ }^{2}$ and Ding-Kwo Chang ${ }^{1}$ \\ ${ }^{1}$ Institute of Chemistry, Academia Sinica, Taipei 11529, Taiwan \\ ${ }^{2}$ Institute of Biotechnology, Department of Life Science, National Tsing Hua University, Hsinchu 30013, Taiwan
}

Correspondence should be addressed to Suh-Chin Wu, scwu@life.nthu.edu.tw and Ding-Kwo Chang, dkc@chem.sinica.edu.tw

Received 15 June 2010; Accepted 15 October 2010

Academic Editor: Robert Blumenthal

Copyright ( 2010 Yi-Shin Pan et al. This is an open access article distributed under the Creative Commons Attribution License, which permits unrestricted use, distribution, and reproduction in any medium, provided the original work is properly cited.

\begin{abstract}
We have constructed virus-like particles (VLPs) harboring hemagglutinin (HA), neuraminidase (NA), matrix protein 1 (M1) , and proton channel protein (M2) using baculovirus as a vector in the SF9 insect cell. The size of the expressed VLP was estimated to be $\sim 100 \mathrm{~nm}$ by light scattering experiment and transmission electron microscopy. Recognition of HA on the VLP surface by the HA2-specific monoclonal antibody IIF4 at acidic $\mathrm{pH}$, as probed by surface plasmon resonance, indicated the $\mathrm{pH}$-induced structural rearrangement of HA. Uptake of the particle by A549 mediated by HA-sialylose receptor interaction was visualized by the fluorescent-labeled VLP. The HA-promoted cell-virus fusion activity was illustrated by fluorescence imaging on the Jurkat cells incubated with rhodamine-loaded VLP performed at fusogenic $\mathrm{pH}$. Furthermore, the green fluorescence protein (GFP) was fused to NA to produce VLP with a pH-sensitive probe, expanding the use of VLP as an antigen carrier and a tool for viral tracking.
\end{abstract}

\section{Introduction}

Virus-like particle (VLP) has been extensively studied for its vaccine capacity in the last 20 years. More than a dozen of VLP-based vaccines have been tested in clinical trials. Two of them against hepatitis B and human papilloma viruses are commercially available as prophylactics [1]. The merits of VLP-based vaccine rest on its viral mimicry and devoid of genetic materials, hence alleviating the safety concerns [2]. The repetitive and ordered structures of VLPs are conducive to opsonization, resulting in enhanced phagocytosis [3, 4], and are capable to activate $\mathrm{B}$ cells in a $\mathrm{T}$ cell-independent manner $[5,6]$. Owing to the virus-like dimension and particulate nature, VLPs are easily taken up by antigenpresenting cells (APCs) $[7,8]$ and more efficient in crosspresentation of antigens to MHC I molecules compared to the soluble antigen and hence the possibility of activating antigen-specific cytotoxic T lymphocytes (CTLs) [9].

Although the VLP-based vaccines have the potential to induce CTL response, most of them favor the production of humoral immunity but poorly evoke CTL response if additional stimuli for innate immune system and, in particular, APC were neglected [1]. It is somewhat surprising that VLPs derived from baculovirus system incorporating viral structural proteins of influenza virus were found to induce both cell-mediated and humoral immunity to confer full protection from viral challenge [10-12]. This distinct feature drew our attention on the interaction between VLPs and cells since most of the VLP-based strategies for vaccine development do not involve antigens with functions of ligand binding and membrane fusion in contrast with the hemagglutinin of influenza VLP.

Influenza A virus is an enveloped RNA virus with three transmembrane proteins: hemagglutinin (HA), neuraminidase (NA), and ion channel protein (M2) along with matrix protein 1 (M1) underlying the viral envelope. The major tasks of these proteins include ligand binding and membrane fusion for HA $[13,14]$, spreading of viral progeny and facilitating entry of the virus for NA [15-17], proton transfer for viral uncoating as well as assembly and budding 
TAble 1: Primer sequence used in pFastbac Dual vector construction.

\begin{tabular}{|c|c|}
\hline Primer & Sequence $5^{\prime}-3^{\prime}$ \\
\hline HA forward & $\begin{array}{l}\text { GATCCGCCACCATGAAATTCTTAGTCAACG- } \\
\text { TTGCCC }\end{array}$ \\
\hline HA reverse & $\begin{array}{l}\text { GCGGCCGCCCGTCTTCCATCTTCTTGTTTA- } \\
\text { AATTCT }\end{array}$ \\
\hline NA forward & $\begin{array}{l}\text { CTCGAGGCCACCATGAATCCAAACCAG- } \\
\text { AAAATAAT }\end{array}$ \\
\hline NA reverse & GGTACCCTACTTGTCAATGGTGAACG \\
\hline M1 forward & $\begin{array}{l}\text { CTCGAGGCCACCATGAGTCTTCTAACC- } \\
\text { GAGGTC }\end{array}$ \\
\hline M1 reverse & GGTACCTCACTTGAATCGTTGCATCTG \\
\hline M2 forward & $\begin{array}{l}\text { GAATCCGCCACCATGAGTCTTCTAACCGAG- } \\
\text { GT }\end{array}$ \\
\hline M2 reverse & AAGCTTTTACTCCAGCTCTATGTTGA \\
\hline $\begin{array}{l}\text { NA-EGFP } \\
\text { forward-1 }\end{array}$ & $\begin{array}{l}\text { CTCGAGGCCACCATGAATCCAAACCAG- } \\
\text { AAAATAATA }\end{array}$ \\
\hline $\begin{array}{l}\text { NA-EGFP } \\
\text { forward-2 }\end{array}$ & $\begin{array}{l}\text { CATTACCTATAAAGTTGTTGCTGGGGTGAG- } \\
\text { CAAGGGCGAGGAG }\end{array}$ \\
\hline $\begin{array}{l}\text { NA-EGFP } \\
\text { reverse-1 }\end{array}$ & $\begin{array}{l}\text { TGAACAGCTCCTCGCCCTTGCTCACCCCAG- } \\
\text { CAACAACTTTATAGGT }\end{array}$ \\
\hline $\begin{array}{l}\text { NA-EGFP } \\
\text { reverse-2 }\end{array}$ & GGTACCCTATTACTTGTACAGCTCGTC \\
\hline
\end{tabular}

of the virus for M2 [18-20], recruitment of viral components to the assembly site, and a major driving force for viral budding for M1 [21, 22].

Several laboratories have produced insect cell-derived VLPs encompassing the above-mentioned influenza proteins for vaccine development [23]. However, there has been no report on the characterization of the interaction between VLPs and cells. To afford a better understanding of these interactions, we used fluorescent images and dye dequenching in this study in the hope of shedding some light on the mechanism of antigen presentation, and virus-mediated membrane fusion and its inhibition.

\section{Materials and Methods}

2.1. Plasmid Construction. HA (A/Thailand/1(KAN-1)/2004 /H5N1), NA (A/Viet Nam/1203/2004/H5N1), M1 (A/WSN/ $33 / \mathrm{H} 1 \mathrm{~N} 1$ ) and $\mathrm{M} 2$ (A/WSN/33/H1N1), influenza cDNA sequences were amplified by PCR (primer sequences were listed in the Table 1). The HA PCR products were cloned into BamHI/NotI site under the control of the polyhedron promoter, the M1 PCR products into XhoI/KpnI site under p10 promoter of the pFastbac Dual baculovirus transfer vector (Invitrogen), the M2 PCR products into EcoRI /HindIII site under the polyhedron promoter, and the NA PCR products into XhoI/KpnI site under p10 promoter of the pFastbac Dual baculovirus transfer vector (Invitrogen), and the NA-EGFP PCR products into XhoI/KpnI site under p10 promoter of the pFastbac Dual baculovirus transfer vector (Invitrogen). All the inserted sequences were confirmed by DNA sequence analysis (Mission Biotech Inc., Taipei, Taiwan).
2.2. Generation of Recombinant Baculoviruses. Production of recombinant baculoviruses followed the manufacturer's manual of Bac-to-Bac baculovirus system (Invitrogen). Briefly, the pFastbac Dual plasmids were transformed into E.coli strain DH10Bac (Invitrogen) and selected on LB plate containing kanamycin (Invitrogen), gentamicin (Invitrogen), tetracycline (Invitrogen), Bluo-gal (Invitrogen), and IPTG (BioRad). The recombinant bacmids were confirmed by sequencing and then transfected into Spodoptera frugiperda (Sf9) cells for recombinant baculovirus packaging via the aid of Cellfectin Reagent (Invitrogen). After 4 days, the recombinant baculovirus in the supernatant was collected as P1 viral stock and further amplified as P2 viral stock for VLP purification. The virus titer of viral stock was determined by the end-point dilution in Sf9 cells [24].

2.3. Production and Purification of VLP. The Sf9 insect cells (cat. no. 11496-015, Invitrogen) were maintained as suspension cultures in sf900 II SFM (Invitrogen) at $27^{\circ} \mathrm{C}$. For the production of $\mathrm{HA}^{+} \mathrm{VLP}, 300 \mathrm{ml}$ of Sf9 cells at $2 \times 10^{6} \mathrm{cells} / \mathrm{ml}$ were coinfected with Dual HA, M1 and Dual NA, M2 recombinant baculovirus at MOI of 3 and 1 , respectively, whereas for the production of $\mathrm{HA}^{-}$VLP, the Dual HA, M1 recombinant baculovirus were replaced with M1 only recombinant baculovirus. To produce NAEGFP VLP, the same infection procedure was carried out except for the replacement of Dual NA, M2 with Dual NAEGFP, M2 recombinant baculovirus. At $72 \mathrm{~h}$ post-infection, the supernatant was collected by centrifugation at $12000 \mathrm{~g}$ for $20 \mathrm{~min}$. The VLPs were precipitated at $33000 \mathrm{rpm}$ and $4^{\circ} \mathrm{C}$ for $2 \mathrm{~h}$ (RPS40ST rotor, Hitachi). The particles were resuspended in PBS buffer, loaded on a $0-60 \%(\mathrm{w} / \mathrm{v})$ discontinuous sucrose gradient, and centrifuged for $4 \mathrm{~h}$ at $33000 \mathrm{rpm}$ and $4^{\circ} \mathrm{C}$ (RPS40ST rotor, Hitachi). After ultracentrifugation, fractions were collected from the top of the gradient and analyzed by Western blotting [25]. Fractions containing $\mathrm{HA}, \mathrm{NA}, \mathrm{M} 1$, and M2 proteins were collected, and the protein concentration was determined by BCA protein assay kit (cat. 23225, Pierce).

2.4. Western Blotting for Detection of the Expressed Viral Proteins. Protein samples were resolved by $12.5 \%$ SDS polyacrylamide gel and then transferred to PVDF membranes. The membrane blots were blocked with 5\% nonfat milk in Tris-buffered saline containing $0.1 \%$ Tween-20 and probed with primary antibodies against HA (abcam ab21297), NA (abcam ab70759), M1 (abcam ab25918), M2 (novus NB100-2073), separately. The presence of each protein was detected by HRP-conjugated secondary antibody and Enhanced Chemiluminescence (ECL) plus western blot detection system (Amersham Bioscience). The blot images were captured by the LAS-3000 imaging system (Fujifilm, Tokyo, Japan).

2.5. Fluorescent Dye Labeling and Fluorescence Microscopy. The fluorescent dye labeling was performed as described previously with minor modification [26]. VLPs suspended 
in PBS were mixed with equal volume of R18- or DiOcontaining PBS to final concentration of $10 \mu \mathrm{M}$ of R18 or $\mathrm{DiO}$ (Molecular probes, Invitrogen). The mixture was incubated in dark for $1 \mathrm{~h}$ at room temperature for R18 labeling while incubated for $20 \mathrm{~min}$ at $37^{\circ} \mathrm{C}$ for $\mathrm{DiO}$ incorporation. The R18-labeled VLPs were washed three times with PBS, and the unincorporated dyes were filtered away by a Microcon devise with MW cutoff of $50 \mathrm{kDa}$. The fluorecentlabeled VLPs were mounted on a glass support and visualized by inverted fluorescence microscope (Aviovert, Carl Zeiss Inc.) with oil immersion objective (Plan-Apo 100X, N.A. 1.4). The images were processed by MetaMorph software (Carl Zeiss Meditec, Gottingen Germany).

2.6. Dynamic Light Scattering (DLS) and Transmission Electron Microscope (TEM). The particle size measurement was executed on the miniDAWN (Wyatt Technology Corp., Santa Barbara, CA) equipped with a microCUVETTE and a $30 \mathrm{~mW}, 685 \mathrm{~nm}$ GaAs laser light source. One milliliter of PBS was filtrated through a $0.02 \mu \mathrm{m}$ inorganic membrane filter (Anodisc, Whatman International Ltd., Maidstone, England) as the DLS background. For the hydrodynamic radius ( $\mathrm{Rh}$ ) measurement, one microliter of VLP solution was directly mixed with the PBS and transferred in the microCUVETTE. Data collection and analysis were performed on the ASTRA V software (Wyatt Technology Corp., Santa Barbara, CA).

The morphology of the influenza VLP was observed by transmission electron microscope JEM 2010 (Jeol Ltd., Tokyo Japan). $3 \mu \mathrm{l}$ of diluted influenza VLPs were loaded onto formvar-carbon-coated 300-mesh copper grids (Polysciences Inc.) and allowed to absorb for 3 minutes. The grids were wicked dry with filter paper, rinsed once with PBS, and negatively stained with $1 \%$ ammonium phosphotungstate $\mathrm{pH}$ 7. Grids were examined by TEM at $200 \mathrm{kV}$ accelerating voltage for the presence of influenza virus.

2.7. Spectroscopic Measurements. $20 \mu \mathrm{l}$ of NA-EGFP VLP (total protein amount $15.6 \mu \mathrm{g}$ ) was diluted in $50 \mu \mathrm{l}$ of PBS with varying $\mathrm{pH}$ by titration with $25 \mathrm{mM}$ of citric acid. The fluorescent signal was recorded on a fluorescence spectrophotometer F2500 (Hitachi). The excitation wavelength was $470 \mathrm{~nm}$ while emission spectra spanned 490 to $560 \mathrm{~nm}$. Excitation and emission slit widths were set at 2.5 and $10 \mathrm{~nm}$, respectively.

2.8. Endocytosis of VLPs by A549 Cells. The fluorescentlabeled VLPs were diluted in ice-cold DMEM medium containing $50 \mathrm{mM} \mathrm{NH}_{4} \mathrm{Cl}$ and added to cover slips with a monolayer of grown A549 cells. The maximum amount of $\mathrm{NH}_{4} \mathrm{Cl}$ was tested for $24 \mathrm{~h}$ for minimal cellular morphological change. The cover slips were stood on ice for $1 \mathrm{~h}$ to prevent VLP engulfed by pinocytosis. To show that the endocytotic process is mediated by the binding between viral HA and cellular sialylated receptors, A549 cells were treated with neuraminidase from Vibrio cholerae (Sigma) at $4 \times 10^{-2} \mathrm{unit} / \mathrm{ml}$ and $37^{\circ} \mathrm{C}$ for $2 \mathrm{~h}$ prior to the addition of fluorescent-labeled VLPs. After $1 \mathrm{~h}$ incubation, the unbound VLPs were washed away with ice-cold DMEM medium, and the cells were cultured in DMEM medium containing $50 \mathrm{mM}$
$\mathrm{NH}_{4} \mathrm{Cl}$ at $37^{\circ} \mathrm{C}$ for $2 \mathrm{~h}$ [27], which was replaced with a medium containing $5 \mu \mathrm{M}$ of DiD dye for $15 \mathrm{~min}$ before the cells were washed extensively with PBS and fixed with $4 \%$ paraformaldehyde in PBS at room temperature for $10 \mathrm{~min}$ and mounted with 50\% glycerol in PBS. The R18- and DiO-labeled VLPs taken up by A549 cells were observed by Zeiss LSM510 META laser scanning confocal microscope using oil immersion objective (Plan-Apo 100x, N. A. 1.4) in multitrack channel mode. Excitation wavelengths and emission filters were $488 \mathrm{~nm} /$ band-pass $500-530 \mathrm{~nm}$ for EGFP and DiO, $561 \mathrm{~nm} /$ band-pass 575-630 nm for R18, and $561 \mathrm{~nm} /$ band -pass 651-704 nm for DiD. The images were analyzed by LSM image browser (Zeiss).

2.9. Inhibition of VLP Binding. $5 \mu \mathrm{l}$ of R18-labeled VLPs (protein estimation $2.4 \mu \mathrm{g}$ ) were mixed with variant concentration of fetuin in final volume of $200 \mu \mathrm{l}$ and incubated at R.T. for $5 \mathrm{~min}$. The mixtures were then added into equal volume of Jurkat cells $\left(1 \times 10^{6}\right.$ cells $)$ and incubated at $37^{\circ} \mathrm{C}$ for $10 \mathrm{~min}$. The cell-bound VLPs were collected by centrifugation at $200 \times \mathrm{g}$ for $5 \mathrm{~min}$ and lysed with octaethylene glycol dodecyl ether $\left(\mathrm{C}_{12} \mathrm{E}_{8}\right.$, Calbiochem $)$ in a final concentration of $3 \mathrm{mM}$. The R18 signal was detected by fluorescence spectrophotometer F4500 (Hitachi) with excitation at $540 \mathrm{~nm}$ and emission at $578 \mathrm{~nm}$. Excitation and emission slit widths were set at 2.5 and $10 \mathrm{~nm}$, respectively.

2.10. Monoclonal Antibody Binding to HA. Experiments of surface plasmon resonance (SPR) were conducted to evaluate the binding affinity of HA2-specific mAb IIF4 to $\mathrm{HA}^{+}$and $H^{-}{ }^{-}$VLPs. In brief, the VLP was immobilized on an activated CM5 sensor chip, which was placed in the chamber of a BIACORE 3000 biosensor system [28] (BIAcore AB, Uppsala, Sweden). IIF4 used as the analyte was injected over the CM5 sensor chip at $10 \mu \mathrm{l} / \mathrm{min}$ flow rate at $\mathrm{pH} 7.4$ or 5.0 in sodium phosphate buffer to examine the $\mathrm{pH}$-dependent conformational change as observed for the native influenza virus. The sensor surface was regenerated with solution of $0.1 \mathrm{M} \mathrm{NaCl}$ and $0.02 \mathrm{~N} \mathrm{NaOH}$. The SPR kinetic data were fitted by the BIAevaluation 3.1 software.

\subsection{Immunofluorescence Detection of VLP. $20 \mu \mathrm{l}$ of VLP} was diluted in $200 \mu \mathrm{l}$ of PBS, and then added onto poly-Llysine-treated coverslip on ice for $2 \mathrm{~h}$. After PBS washing, the $\mathrm{pH} 5$ treated VLP was incubated with low $\mathrm{pH}$ buffer (10 mM HEPES, $10 \mathrm{mM}$ MES in PBS, pH 5.0) for $2 \mathrm{~min}$, rinsed with PBS, and fixed with $4 \%$ paraformaldehyde and subsequently blocked with $10 \%$ FBS in PBS at RT for $1 \mathrm{~h}$. The VLP was probed with IIF4 mAB (kindly provided by Dr. Vareckova, 100x diluted) and subsequently hybridized with FITC conjugated antimouse IgG (500x diluted) at $37^{\circ} \mathrm{C}$ for $1 \mathrm{~h}$. The coverslips were mounted on a microscope slide and visualized with fluorescence microscope (Carl Zeiss, Germany). The images were captured and processed with Metamorph software (Molecular Devices, CA, USA ).

2.12. Fusion of R-18-Labeled VLP with Jurkat Cells. The fusion process was monitored by fluorescence dequenching 


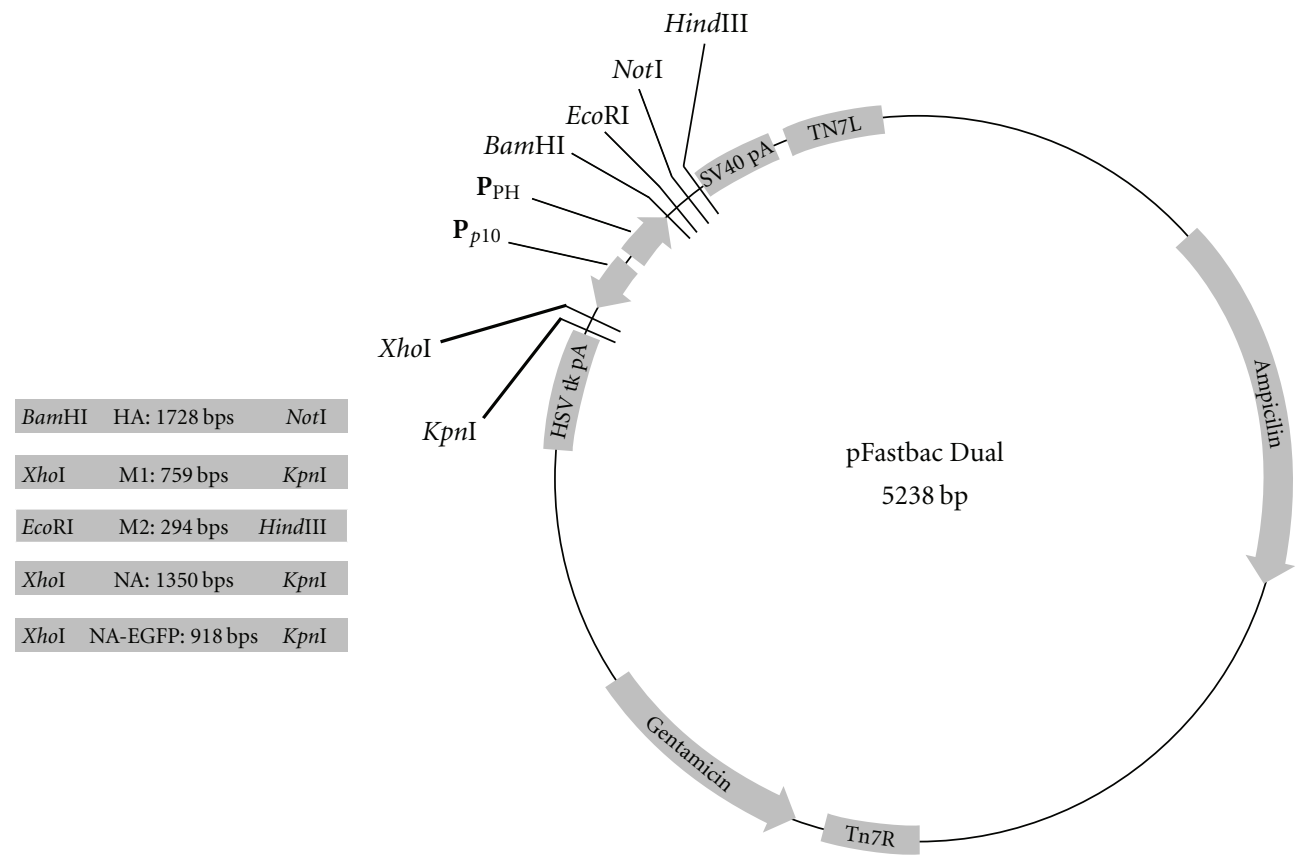

FIGURE 1: Construction of pFastbac Dual plasmid. Viral genes were flanked two different restriction sites while PCR amplification and ligated with pFastbac Dual vector as indicated. HA, M1 and M2, NA genes were paired and cloned in separate pFastbac Dual vectors and used for bacmids recombination. When constructing pFastbac Dual vectors for $\mathrm{HA}^{-}$and NA-EGFP VLPs, HA gene was omitted, and NA was replaced with NA-EGFP fusion gene, respectively. Tn7L and Tn7R were left and right arms of bacterial transposon Tn7 for gene recombination.

of R18 due to the lateral diffusion and dilution from viral to cellular membrane as a result of membrane fusion $[29,30]$.

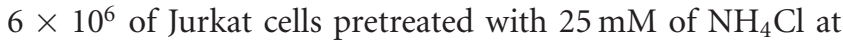
$37^{\circ} \mathrm{C}$ for $15 \mathrm{~min}$ were suspended in $500 \mu \mathrm{l}$ of PBS containing $25 \mathrm{mM}$ of $\mathrm{NH}_{4} \mathrm{Cl}$ and added $10 \mu \mathrm{l}$ of R18-labeled VLPs (protein estimation $4.7 \mu \mathrm{g}$ ) and then incubated at $37^{\circ} \mathrm{C}$ for $10 \mathrm{~min}$. The cells were sedimented by centrifugation at $4^{\circ} \mathrm{C}$ for $5 \mathrm{~min}$ at $200 \times \mathrm{g}$ and rapidly resuspended in $1 \mathrm{ml}$ of PBS. Fusion of VLPs with plasma membrane was triggered by lowering the $\mathrm{pH}$ to 5 with $0.25 \mathrm{M}$ of citric acid. The maximum fluorescence was obtained by lysing the viral and cellular membrane with $\mathrm{C}_{12} \mathrm{E}_{8}$ at final concentration of $3 \mathrm{mM}$ after each experiment. The fluorescent increase was detected by fluorescence spectrophotometer F4500 (Hitachi) with excitation at $540 \mathrm{~nm}$ and emission at $578 \mathrm{~nm}$. Excitation and emission slit widths were set at 2.5 and $10 \mathrm{~nm}$, respectively. The fluorescent images were captured by inverted fluorescence microscope (Aviovert, Carl Zeiss Inc.) with oil immersion objective (Plan-Apo 40X, N.A. 1.3) and processed by MetaMorph software (Carl Zeiss Meditec, Gottingen, Germany).

\section{Results}

3.1. Construction and Characterization of Influenza VLP from Baculovirus/Sf9 Insect Cell Expression System. Figure 1 illustrates the construction of pFastbac Dual plasmids containing influenza M1/HA, NA/M2, -/HA, and NA-EGFP/M2 gene pairs for the production of recombinant baculoviruses. Using these recombinant baculoviruses, $\mathrm{HA}^{+}$VLPs, $\mathrm{HA}^{-}$VLPs, and
NA-EGFP VLP were generated. Figure 2 displays the Western blot results (panel a) of the expressed proteins incorporated in $\mathrm{HA}^{+}$and $\mathrm{HA}^{-}$VLPs. The incorporated proteins were expressed at similar level except for HA protein devoid in $\mathrm{HA}^{-}$VLPs as expected. It is noted that the fraction of cleavage for hemagglutinin in the present expression system is estimated to be $33.7 \%$. The morphology of the expressed VLP as visualized by transmission electron microscopy shown in Figure 2(b) is nearly spherical with a diameter of $\sim 100 \mathrm{~nm}$, close to the virus in the native context $[31,32]$. The radius of VLP measured by light scattering was $63.3 \pm$ $0.13 \mathrm{~nm}$ with a convergent size distribution (Figure 2(c)).

3.2. Endocytosis of VLP in A549 Cells. Binding of hemagglutinins to cellular sialylated receptors initiates the host endocytotic process for influenza virus entry [33-35]. Equal amount of $\mathrm{HA}^{+} \mathrm{VLP}$ or $\mathrm{HA}^{-} \mathrm{VLP}$, with regard to each protein concentration, was added to A549 cells. Compared to $\mathrm{HA}^{-} \mathrm{VLP}, \mathrm{HA}$-incorporated VLPs were significantly endocytosed by A549 cells. To confirm that the endocytic process is mediated by HA binding to the sialylated receptor, A549 cells were treated with neuraminidase from Vibrio cholerae. After $2 \mathrm{~h}$ of treatment, most of the sialic acids exposed on the cell surface were removed as confirmed by sialic acid-specific lectin staining (see Figure S1 in Supplementary Material available online at doi:10.11/2010/506363). As shown in Figure 3, removal of sialic acids starkly decreased $\mathrm{HA}^{+} \mathrm{VLP}$ engulfed by A549 cells. Also, attachment of VLP to another suspended cell line Jurkat cell could be hampered by fetuin (Figure 3(f)), which is a sialylated glycoprotein [36, 37] 


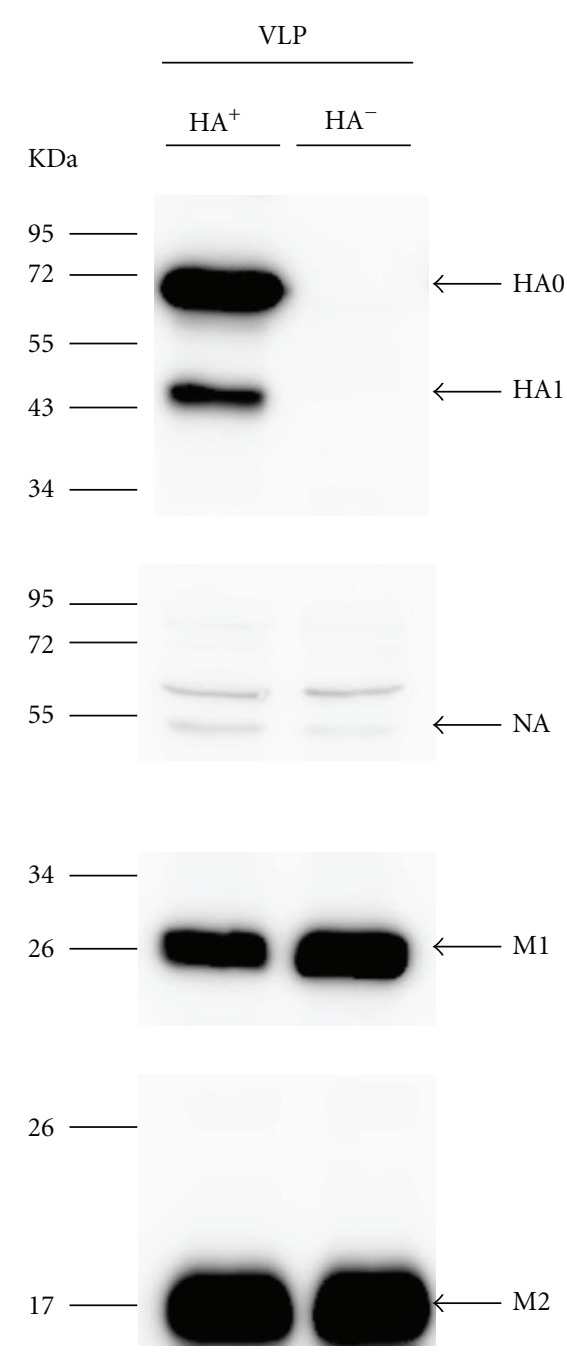

(a)

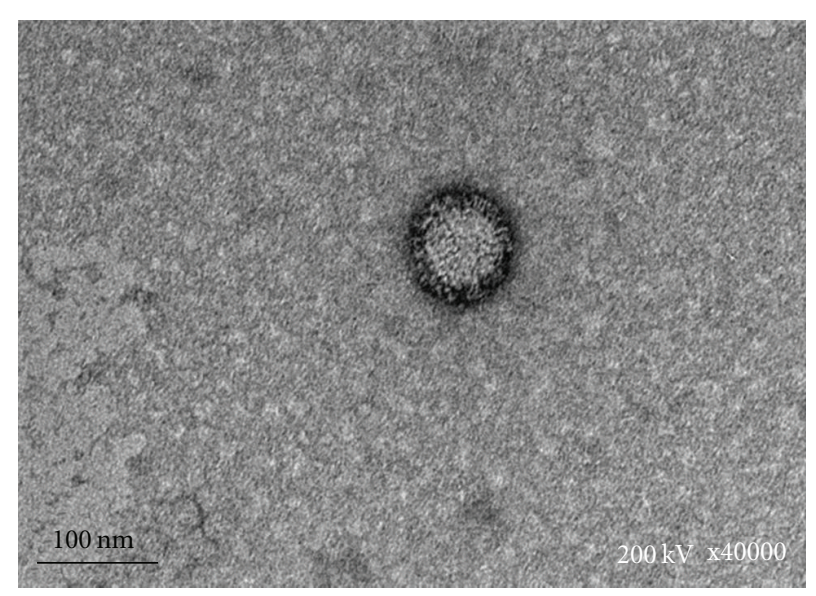

(b)

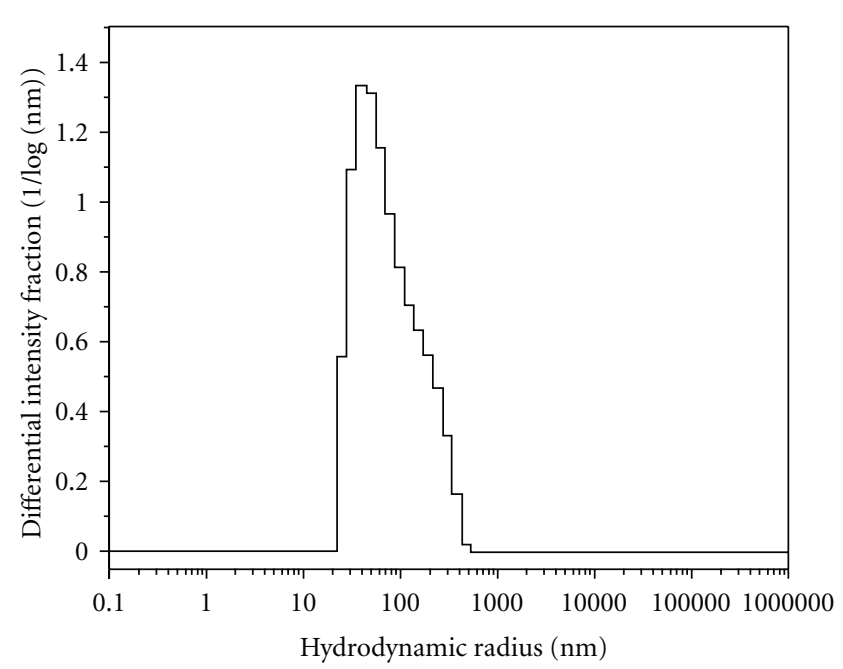

(c)

FIgURE 2: Characterization of insect cell-derived VLP. Equal amounts of VLP proteins were resolved by $12.5 \%$ discontinuous SDS polyacrylamide gel and detected by four different primary antibodies against HA, NA, M1, M2 (a). The morphology and particle size distribution of $\mathrm{HA}^{+}$VLP were measured by transmission electron microscope (b) and dynamic light scattering (c), respectively.

and used as a model inhibitor for influenza virus infection [38-41], in a dose-dependent manner. Taken together, the $\mathrm{HA}^{+}$VLP was endocytosed by A549 cells through the binding of viral HA and cellular sialylated receptor.

\subsection{HA2 Exposure Recognized by Monoclonal Antibody IIF4} in Acidic Environment. IIF4 mAb has been reported to be specific to the epitope within HA2 aa 125-175 of the H3 subtype of influenza A virus and is well cross-reacting with $\mathrm{H} 4$ and $\mathrm{H} 5$ viruses [42-44]. Previous studies demonstrated that IIF4 epitopes on HA2 became accessible after acid treatment on HA $[42,45]$. The binding affinity of HA2specific mAb IIF4 to $\mathrm{HA}^{+}$VLPs at acidic $\mathrm{pH}$ was $0.18 \pm$ $0.05 \mathrm{nM}, 32$-fold higher than binding affinity at neutral $\mathrm{pH}$ (Figures 4(a) and 4(c) and Table 2). This implied that the
HA on VLP membrane could expose HA2 subunit leading to fusion of the viral and cellular membranes as a result of lowered $\mathrm{pH}$.

To further support the SPR result that the $\mathrm{HA}^{+} \mathrm{VLP}$ has much higher affinity to IIF4 mAb at $\mathrm{pH} 5$ than at $\mathrm{pH}$ 7.4, immunofluorescence staining was performed. As shown in Figure $4(\mathrm{~d})$ acidic buffer-treated $\mathrm{HA}^{+}$VLP was recognizable by HA2 IIF4 $\mathrm{mAb}$ whereas at natural $\mathrm{pH} \mathrm{HA}{ }^{+}$VLP and $\mathrm{HA}^{-}$VLP were not, in agreement with the SPR measurement and indicating that the HA2 portion on the VLP is exposed at acidic $\mathrm{pH}$.

3.4. Fusion of Virus-Like Particles with Jurkat Cells. Fluorescent dequenching of R18 was employed to monitor the fusion process of influenza virus with culture cells 


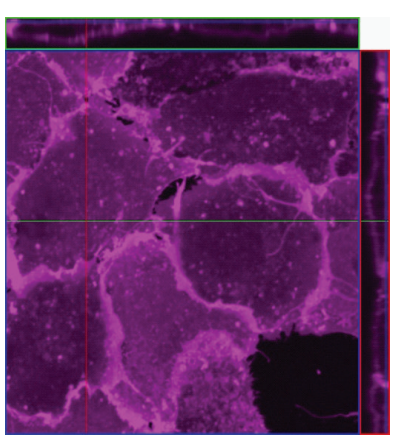

(a)

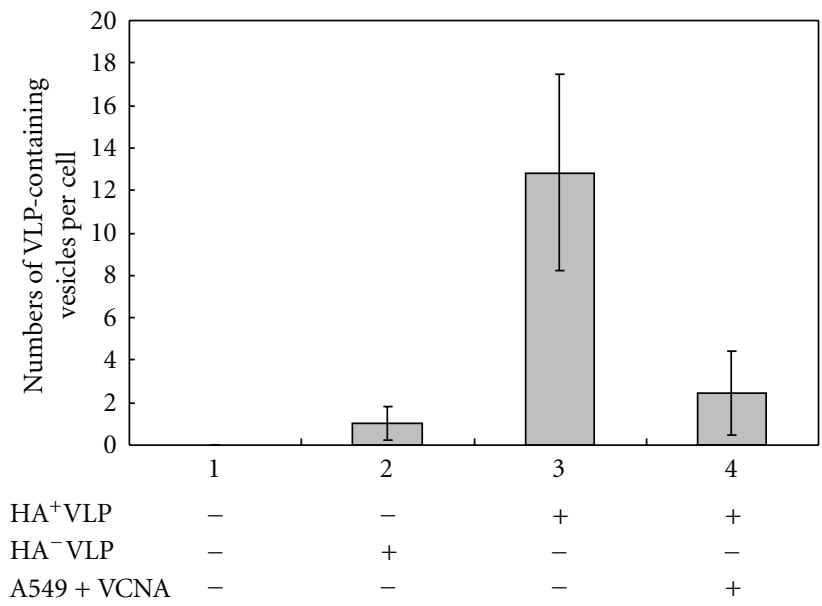

(e)

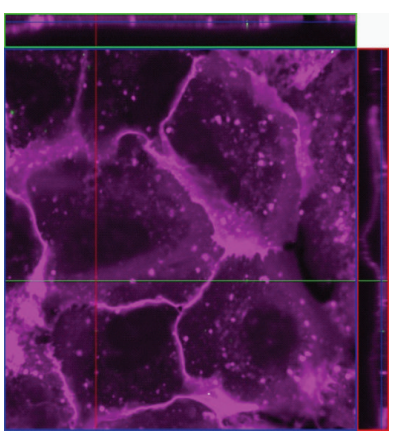

(b)

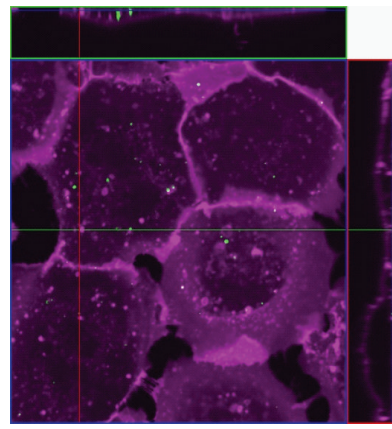

(c)

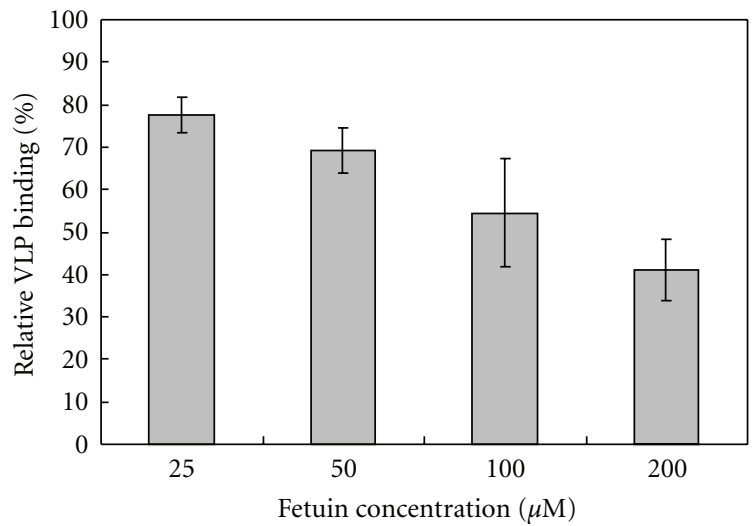

(f)

FIgURE 3: HA-mediated endocytosis of VLP in A549 cells. A549 cells were added to VLPs labeled with DiO dye and incubated on ice for $1 \mathrm{~h}$. The unbound VLPs were washed away, and the cells were incubated at $37^{\circ} \mathrm{C}$ for further $2 \mathrm{~h}$. (b) and (c) show A549 cells incubated with $\mathrm{HA}^{-}$VLPs or HA+ VLPs, respectively. (d) displays VCNA-pretreated A549 admixed HA ${ }^{+}$VLP. (a) is a mock control. The upper and right rectangular images of each panel depict horizontal and vertical cross-sections located at green and red lines, respectively. VLPs were labeled with DiO dye (green), and A549 cells were stained with DiD dye (pink). Graph in (e) represents the average of endocytosed VLPs per cell. Graph in (f) depicts the inhibitory effect of fetuin on VLP binding. The values of relative VLP binding was determined by the ratio of R18 signals at each concentration of fetuin to the value obtained for the maximum binding of VLPs without the fetuin treatment.

TABLE 2: Binding affinity of antibody to VLPs.

\begin{tabular}{lccr}
\hline & HA $^{+}$VLP, $p H 7$ & HA $^{+}$VLP, pH5 & HA $^{-}$VLP, pH5 $^{-}$ \\
\hline $\mathrm{K}_{D}(\mathrm{nM})$ & $5.84 \pm 0.23$ & $0.18 \pm 0.05(n=2)$ & $6.28 \pm 0.48(n=2)$ \\
\hline
\end{tabular}

[29, 30]. Thus R18-labeled VLPs were mixed with Jurkat cells and collected by centrifugation of the cells. As shown in Figure 5(a), $\mathrm{HA}^{+}$VLP could adhere to the cells surface and form heterogeneous fluorescent dots while $\mathrm{HA}^{-}$VLP could be barely detected. After lowering the external $\mathrm{pH}$ of the cells, the cell-bound VLPs underwent fusion with the cells, as manifested by more homogenous dispersion of fluorescent signals around the cell. The fusion activity of $\mathrm{HA}^{+}$VLP was reaffirmed by the fluorescence dequenching experiment displayed in Figure 5(b) showing that only $\mathrm{HA}^{+}$VLP induced dramatic fluorescence increase in response to acidic $\mathrm{pH}$.
3.5. Anchorage of NA-EGFP on VLP as a Model for Antigen Incorporation. Since the NA activity has been inferred unnecessary for influenza VLP release from Sf9 insect cells [46-49], the extracellular domain of NA was replaced with the EGFP protein to demonstrate the possibility of accommodating other protein antigens on the VLP membrane to extend the application of influenza VLP as an antigen carrier. To construct the membrane-anchored chimera, the amino terminal 61 amino acids of NA protein were retained and fused with EGFP [50]. The NA-EGFP VLPs were stained with lipophilic dye R18 to characterize the virus-like 


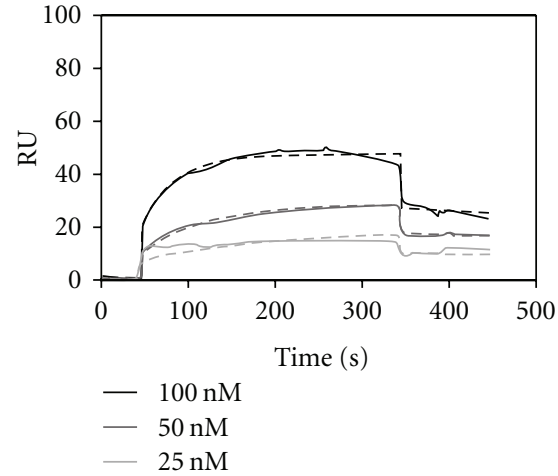

(a)

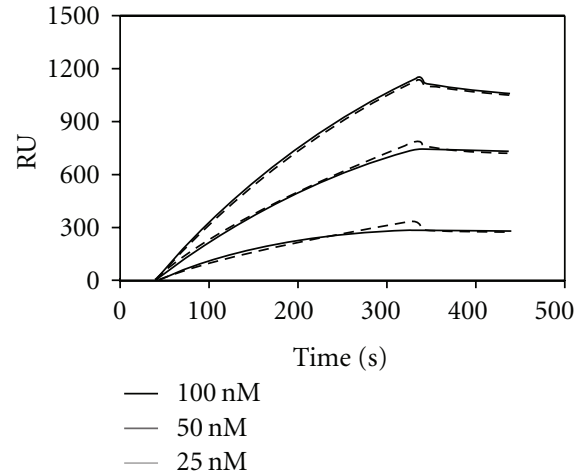

(b)

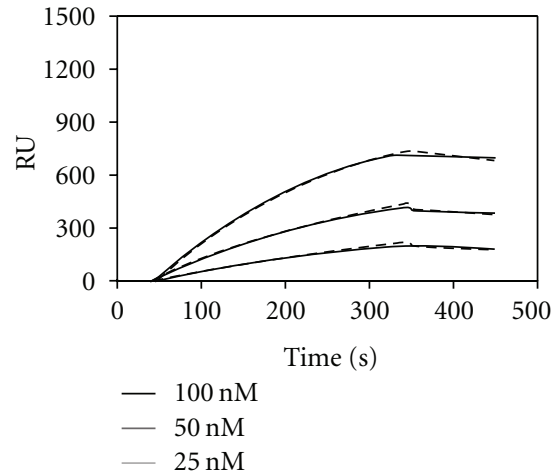

(c)

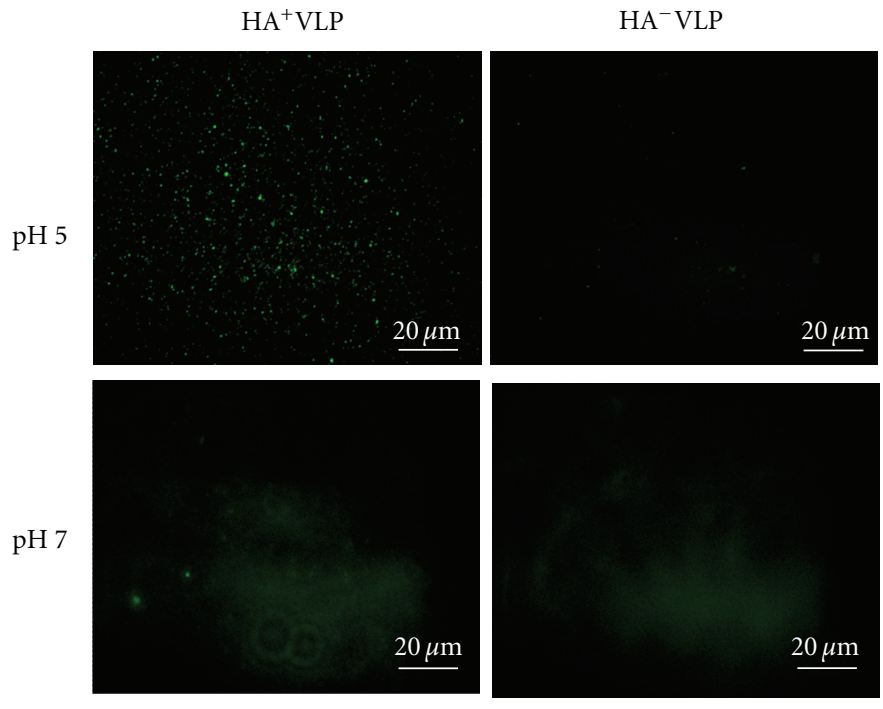

(d)

FIGURE 4: Conformational change of HA on VLPs triggered by low $\mathrm{pH}$. The dissociation constant of mAb IIF4 with HA VLPs or HA $^{-}$VLPs at neutral or acidic $\mathrm{pH}$ was determined by SPR technique: (a) mAb IIF4 bound to HA $\mathrm{HA}^{+}$VLs at pH 7.4; (b) mAb IIF4 bound to HA VLPs $^{+}$ at pH 5.0; (c) mAb IIF4 bound to HA- VLPs at pH 5.0. (d) displays immunofluorescence staining of VLP by mAb IIF4. See "Materials and Methods" for details.

particles incorporated with EGFP. The fluorescent images shown in Figures 6(a)-6(c) were taken by reverse fluorescent microscope. Colocalization of NA-EGFP and R18 confirms that the virus-like particle was loaded with NA-EGFP.

To investigate the uptake of NA-EGFP-incorporated VLP by cells, the VLPs were labeled with R18 and then admixed with $\mathrm{A} 549$ cells at $4^{\circ} \mathrm{C}$ to prevent pinocytosis. As shown in Figures 6(d)-6(f), NA-EGFP VLP can be taken up by A549 cells, and $20.6 \pm 3.7 \%$ of the endocytotic vesicles contain the EGFP fluorescence.

\section{Discussion}

Using pFastbac Dual baculovirus transfer vector, we produced insect cell derived VLPs containing HA, M1, NA, and M2 from influenza virus as well as EGFP-incorporated VLPs. Despite the low NA content or deprived activity in the EGFP-fused NA, the production of VLPs was not impaired.
It was reported that the proteins expressed in Sf9 insect cells were devoid of sialylation as a result of the absence of detectable sialyltransferase activities [46, 47] and CMP-sialic acids $[48,49]$ and were $\mathrm{N}$-glycosylated in high mannose type [51]. It implies that VLP production in insect cells is viable without the aid of NA activity for viral progeny release if HA is incorporated. Also, $\mathrm{N}$-glycans in high mannose type could possibly enhance the HA binding to its sialylated receptors [52] and facilitate the uptake of VLPs by APCs.

From a previous report, HA expression in insect cells was retarded for posttranslational proteolysis[53] as noted in our Western blot result. However, the proteolytic process does not impair the binding capacity of HA but does for membrane fusion [54], as demonstrated in our fusion test (Figure 5). It is noted that some VLPs did not fuse with the plasma membrane of the cells when $\mathrm{pH}$ was lowered to 5 and clumped on the cell surface. It raises an interesting question: since insect cell-derived VLP can 

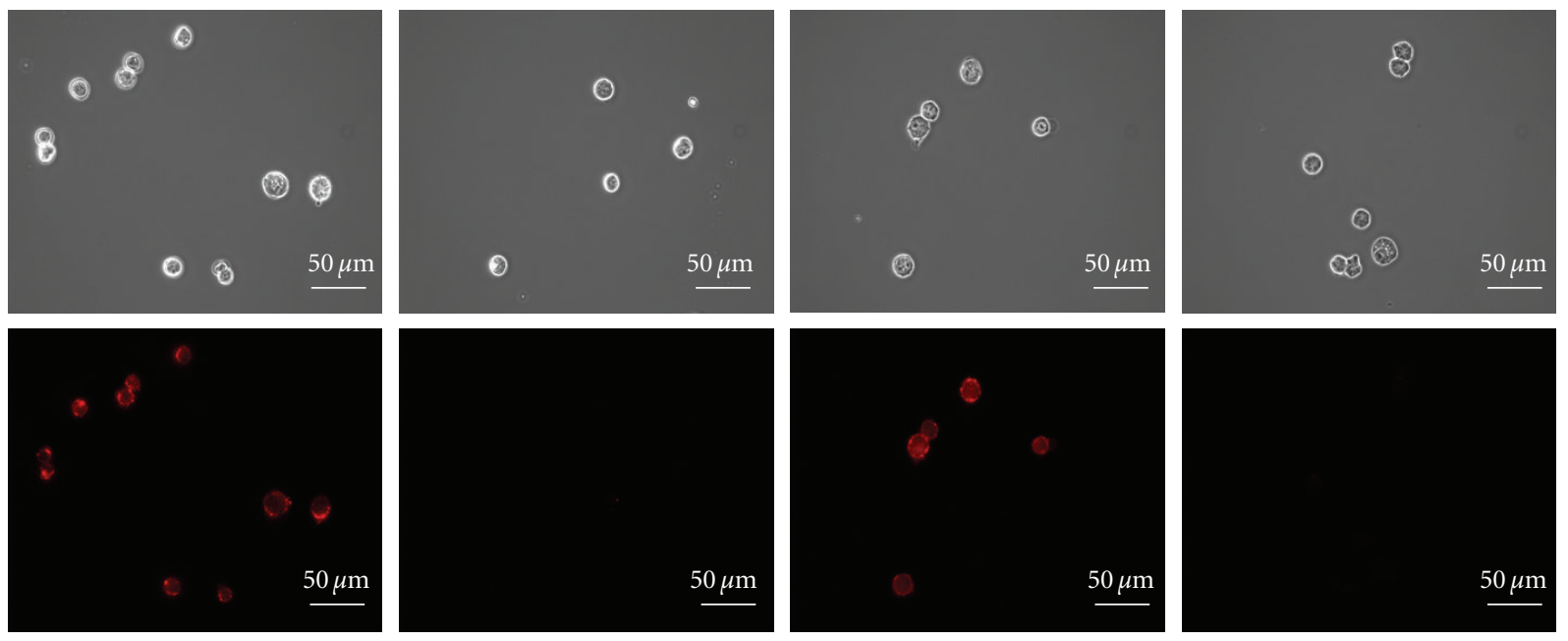

(a)

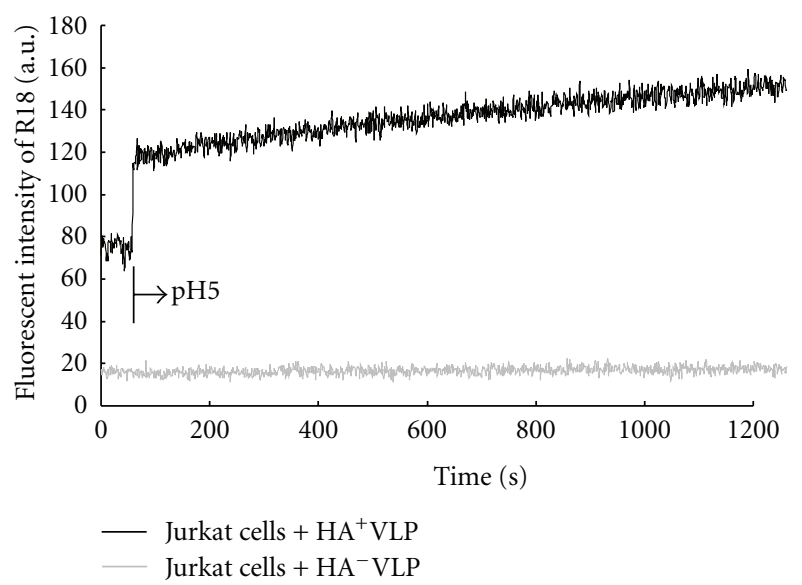

(b)

FIGURE 5: Membrane fusion of VLPs with Jurkat cells. Jurkat cells were mixed with R18-labeled VLPs for 10 min and then collected for detection of the membrane fusion. The fusion process was initiated by lowering the external $\mathrm{pH}$ to 5 . (a) shows $\mathrm{HA}^{+} \mathrm{VLP}^{\mathrm{binding}} \mathrm{HA}^{-}$ VLP binding, $\mathrm{HA}^{+}$VLP bound to cells at pH5 for $2 \mathrm{~min}, \mathrm{HA}^{-}$VLP bound to cells at pH5 for 2 min, from left to right. Graph in (b) depicts the time profile of VLP fusion with plasma membrane triggered by acidification at $1 \mathrm{~min}$ as indicated. The autofluorescence of Jurkat cells obtained as a control was subtracted from the intensity value.

induce cell-mediated immune response [10-12], how are the HA proteins anchored on the late endosomal membrane as a result of HA-induced membrane fusion or accumulated in the endosome lumen involved in cross presentation to MHC I molecules, leading to HA-specific CTL induction? To address this question, mammalian cell-derived influenza VLP with or without proteolytic site in HA protein could be tested for HA-specific CTL induction, protein processing as well as MHC I loading.

The size of expressed VLP is estimated to be $\sim 100 \mathrm{~nm}$ while the average size deduced from dynamic light scattering is $\sim 120 \mathrm{~nm}$. The discrepancy between the two data can be at least partly accounted for by the fact that the latter reports the hydrodynamic diameter of the particle, namely, including the hydrated water molecules surrounding the VLP, thus the larger size [31].
Low pH-triggered conformational change can be detected by mAb IIF4 with the epitope within HA2 125-175, which was exposed upon lowering $\mathrm{pH}$ to 5.0 as deduced from 33 -fold increase in binding affinity to IIF4 when switched to acidic $\mathrm{pH}$. Again, this reaffirms that the constructed VLP can be used as a valid mimic to the native virus for the functional and structural study of hemagglutinin.

Further investigation of the biological activity for the synthesized VLP was performed on fusion to the Jurkat cell membrane induced by HA (Figure 5) as probed by dequenching of the embedded R18 label due to its dilution arising from membrane merger. The result established the function exerted by HA as $\mathrm{HA}^{-}$VLP did not exhibit fusion activity. By measuring the fluorescence intensity of R18, IC50 of fetuin on binding inhibition of $\mathrm{HA}^{+} \mathrm{VLP}$ to Jurkat cell was estimated to be $147 \mu \mathrm{M}(7.1 \mathrm{mg} / \mathrm{ml})$, compared to a previous 


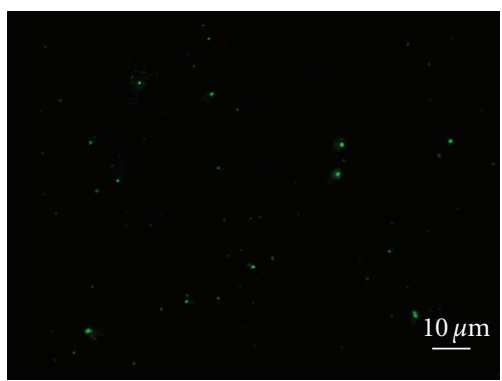

(a)

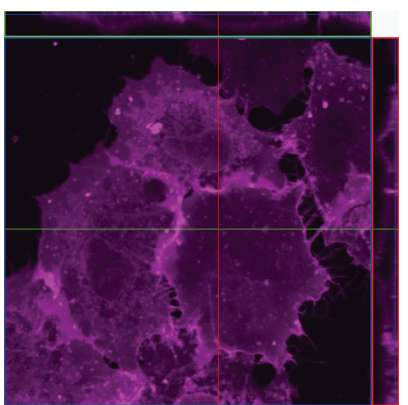

(d)

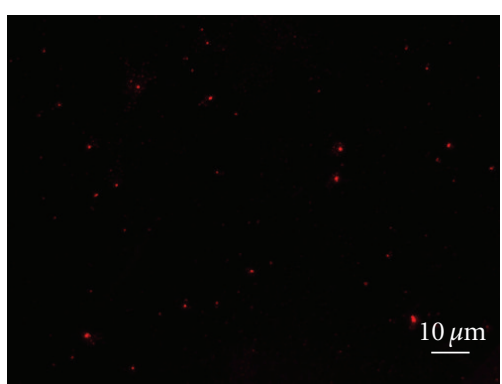

(b)

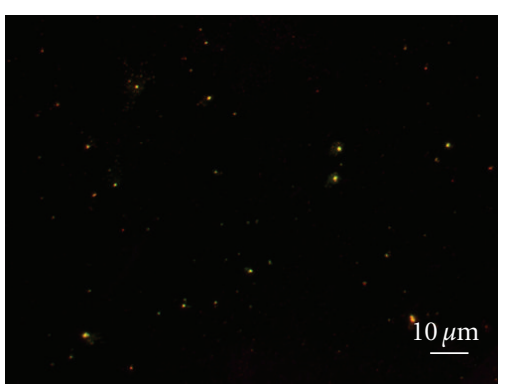

(c)

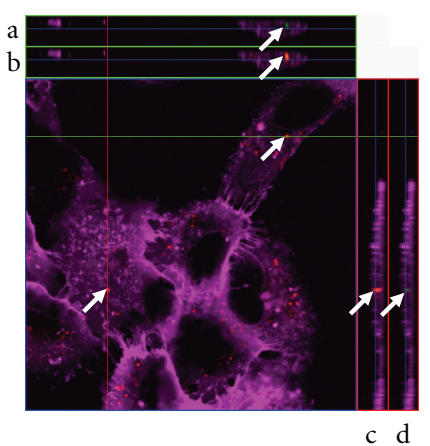

(e)

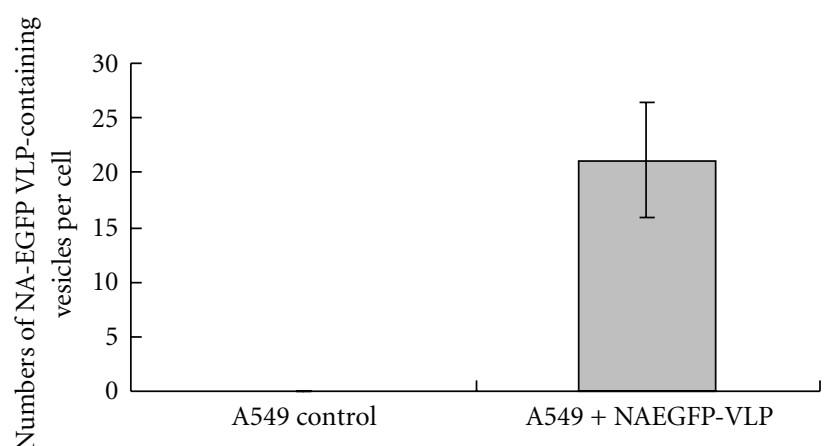

(f)

Figure 6: Endocytosis of NA-EGFP incorporated VLP in A549 cells. The NA-EGFP VLPs were stained with R18 dye. Panels (a) and (b) show the EGFP and R18 signals, respectively. Panel c displays the superimposed images of panels (a) and (b). Panel (e) illustrates the endocytosis of NA-EGFP VLP in A549 cells with panel (d) as a mock control. The upper and right rectangular images of panel (d) and (e) depict horizontal and vertical cross-sections located at green and red lines, respectively. Rectangular images of a and d show the EGFP signals (green) whereas those of b and c show the R18 signals (red). The A549 cells were stained with DiD dye (pink). Graph (f) displays the average number of endocytosed vesicles containing NA-EGFP VLP per cell.

result of $6.4 \mathrm{mg} / \mathrm{ml}$ for inhibition of viral infection by focusforming assays [40]. Based on viral binding and fusion both experiments can be used as screening platforms for inhibitors targeting viral entry.

The fluorescent intensity of EGFP was shown to be influenced by the surrounding $\mathrm{pH}$ [55]. That could beget the low percentage of engulfed vesicles containing EGFP signal. However, it reinforced that the application NA chimera for antigen incorporation in VLP was feasible. Moreover, EGFP was reported as a noninvasive intracellular $\mathrm{pH}$ indicator [56]. The EGFP-VLP could be expanded for its utility as a reporter tag, particularly as a $\mathrm{pH}$ sensor inside the HA-targeted cells. Further study on the time variation of EGFP in the endosome can be conducted to monitor the time course of the fusion process and trafficking of VLP within the cell, which may provide insight into the antigen presentation of the virus and the dynamics and the route of virus invasion in the cell.

\section{Conclusions}

The extensive biophysical characterization of influenza VLP containing M1, HA, NA, and M2 viral structural proteins established a reliable protocol of synthesizing a large quantity of the virus mimetic for use in vaccine study, in particular for the HA as the major antigen. The incorporation of a fluorescent label demonstrates the feasible use of VLP as an antigen carrier as well as a possible tool for microscopic observation of the virus dynamics and interaction with the cellular components within the cell.

\section{Acknowledgments}

The authors are thankful for the instrumental and technical support from the Scientific Instrument Center of Academia Sinica and the assistance of Shu-Chen Shen. The IIF4 monoclonal antibody was kindly supplied by Professor Eva Vareč ková, Institute of Virology, Slovak Academy of Sciences. This paper was supported by the National Science Council (Taiwan) Grant (NSC 96-2321-B-002-028MY2) and Academia Sinica (Taiwan) to Ding-Kwo Chang. Chun-Hung Lin was supported under the Academia Sinica Postdoctoral Fellow Program.

\section{References}

[1] G. T. Jennings and M. F. Bachmann, "The coming of age of virus-like particle vaccines," Biological Chemistry, vol. 389, no. 5, pp. 521-536, 2008. 
[2] B. Chackerian, "Virus-like particles: flexible platforms for vaccine development," Expert Review of Vaccines, vol. 6, no. 3, pp. 381-390, 2007.

[3] N. A. Fanger, K. Wardwell, L. Shen, T. F. Tedder, and P. M. Guyre, "Type I (CD64) and type II (CD32) Fcy receptormediated phagocytosis by human blood dendritic cells," Journal of Immunology, vol. 157, no. 2, pp. 541-548, 1996.

[4] M. Matsushita, Y. Endo, N. Hamasaki, and T. Fujita, "Activation of the lectin complement pathway by ficolins," International Immunopharmacology, vol. 1, no. 3, pp. 359-363, 2001.

[5] M. F. Bachmann, H. Hengartner, and R. M. Zinkernagel, "T helper cell-independent neutralizing $\mathrm{B}$ cell response against vesicular stomatitis virus: role of antigen patterns in B cell induction?" European Journal of Immunology, vol. 25, no. 12, pp. 3445-3451, 1995.

[6] R. Thyagarajan, N. Arunkumar, and W. Song, "Polyvalent antigens stabilize B cell antigen receptor surface signaling microdomains," Journal of Immunology, vol. 170, no. 12, pp. 6099-6106, 2003.

[7] C. V. Harding and R. Song, "Phagocytic processing of exogenous particulate antigens by macrophages for presentation by class I MHC molecules," Journal of Immunology, vol. 153, no. 11, pp. 4925-4933, 1994.

[8] M. Kovacsovics-Bankowski, K. Clark, B. Benacerraf, and K. L. Rock, "Efficient major histocompatibility complex class I presentation of exogenous antigen upon phagocytosis by macrophages," Proceedings of the National Academy of Sciences of the United States of America, vol. 90, no. 11, pp. 4942-4946, 1993.

[9] T. Storni and M. F. Bachmann, "Loading of MHC class I and II presentation pathways by exogenous antigens: a quantitative in vivo comparison," Journal of Immunology, vol. 172, no. 10, pp. 6129-6135, 2004.

[10] R. Arnon and T. Ben-Yedidia, "Preclinical efficacy of a viruslike particle-based vaccine against avian influenza H5N1," Future Microbiology, vol. 4, no. 5, pp. 503-505, 2009.

[11] R. A. Bright, D. M. Carter, C. J. Crevar et al., "Cross-clade protective immune responses to influenza viruses with $\mathrm{H} 5 \mathrm{~N} 1$ HA and NA elicited by an influenza virus-like particle," PLoS One, vol. 3, no. 1, Article ID e1501, 2008.

[12] T. M. Ross, K. Mahmood, C. J. Crevar, K. Schneider-Ohrum, P. M. Heaton, and R. A. Bright, "A trivalent virus-like particle vaccine elicits protective immune responses against seasonal influenza strains in mice and ferrets," PLoS One, vol. 4, no. 6, Article ID e6032, 2009.

[13] J. J. Skehel and D. C. Wiley, "Receptor binding and membrane fusion in virus entry: the influenza hemagglutinin," Annual Review of Biochemistry, vol. 69, pp. 531-569, 2000.

[14] D. A. Steinhauer, "Role of hemagglutinin cleavage for the pathogenicity of influenza virus," Virology, vol. 258, no. 1, pp. $1-20,1999$.

[15] M. N. Matrosovich, T. Y. Matrosovich, T. Gray, N. A. Roberts, and H. D. Klenk, "Neuraminidase is important for the initiation of influenza virus infection in human airway epithelium," Journal of Virology, vol. 78, no. 22, pp. 1266512667, 2004.

[16] P. Palese and R. W. Compans, "Inhibition of influenza virus replication in tissue culture by 2 deoxy 2,3 dehydro $\mathrm{N}$ trifluoroacetylneuraminic acid (FANA): mechanism of action," Journal of General Virology, vol. 33, no. 1, pp. 159-163, 1976.

[17] P. Palese, K. Tobita, M. Ueda, and R. W. Compans, "Characterization of temperature sensitive influenza virus mutants defective in neuraminidase," Virology, vol. 61, no. 2, pp. 397 410, 1974.
[18] P. G. Hughey, P. C. Roberts, L. J. Holsinger, S. L. Zebedee, R. A. Lamb, and R. W. Compans, "Effects of antibody to the influenza A virus M2 protein on M2 surface expression and virus assembly," Virology, vol. 212, no. 2, pp. 411-421, 1995.

[19] J. A. Mould, H. C. Li, C. S. Dudlak et al., "Mechanism for proton conduction of the $\mathrm{M}$ ion channel of influenza A virus," Journal of Biological Chemistry, vol. 275, no. 12, pp. 8592$8599,2000$.

[20] C. Schroeder, H. Heider, E. Möncke-Buchner, and T. I. Lin, "The influenza virus ion channel and maturation cofactor M2 is a cholesterol-binding protein," European Biophysics Journal, vol. 34, no. 1, pp. 52-66, 2005.

[21] P. Gómez-Puertas, C. Albo, E. Pérez-Pastrana, A. Vivo, and A. Portela, "Influenza virus matrix protein is the major driving force in virus budding," Journal of Virology, vol. 74, no. 24, pp. 11538-11547, 2000.

[22] T. Latham and J. M. Galarza, "Formation of wild-type and chimeric influenza virus-like particles following simultaneous expression of only four structural proteins," Journal of Virology, vol. 75, no. 13, pp. 6154-6165, 2001.

[23] S. M. Kang, J. M. Song, FU. S. Quan, and R. W. Compans, "Influenza vaccines based on virus-like particles," Virus Research, vol. 143, no. 2, pp. 140-146, 2009.

[24] P. D. Scotti, "End point dilution and plaque assay methods for titration of cricket paralysis virus in cultured Drosophila cells," Journal of General Virology, vol. 35, no. 2, pp. 393-396, 1977.

[25] P. Pushko, T. M. Tumpey, F. Bu, J. Knell, R. Robinson, and G. Smith, "Influenza virus-like particles comprised of the $\mathrm{HA}, \mathrm{NA}$, and M1 proteins of H9N2 influenza virus induce protective immune responses in BALB/c mice," Vaccine, vol. 23, no. 50, pp. 5751-5759, 2005.

[26] D. Hoekstra, T. De Boer, K. Klappe, and J. Wilschut, "Fluorescence method for measuring the kinetics of fusion between biological membranes," Biochemistry, vol. 23, no. 24, pp. 5675-5681, 1984.

[27] G. Misinzo, P. L. Delputte, and H. J. Nauwynck, "Inhibition of endosome-lysosome system acidification enhances porcine circovirus 2 infection of porcine epithelial cells," Journal of Virology, vol. 82, no. 3, pp. 1128-1135, 2008.

[28] L. W. Abad, M. Neumann, L. Tobias, L. Obenauer-Kutner, S. Jacobs, and C. Cullen, "Development of a biosensor-based method for detection and isotyping of antibody responses to adenoviral-based gene therapy vectors," Analytical Biochemistry, vol. 310, no. 1, pp. 107-113, 2002.

[29] N. Duzgunes, M. C. Pedroso de Lima, L. Stamatatos et al., "Fusion activity and inactivation of influenza virus: kinetics of low $\mathrm{pH}$-induced fusion with cultured cells," Journal of General Virology, vol. 73, no. 1, pp. 27-37, 1992.

[30] I. Nunes-Correia, S. Nir, and M. C. Pedroso De Lima, "Kinetics of influenza virus fusion with the endosomal and plasma membranes of cultured cells. Effect of temperature," Journal of Membrane Biology, vol. 195, no. 1, pp. 21-26, 2003.

[31] Z. Wei, M. Mcevoy, V. Razinkov et al., "Biophysical characterization of influenza virus subpopulations using field flow fractionation and multiangle light scattering: correlation of particle counts, size distribution and infectivity," Journal of Virological Methods, vol. 144, no. 1-2, pp. 122-132, 2007.

[32] M. Yamaguchi, R. Danev, K. Nishiyama, K. Sugawara, and K. Nagayama, "Zernike phase contrast electron microscopy of ice-embedded influenza A virus," Journal of Structural Biology, vol. 162, no. 2, pp. 271-276, 2008.

[33] L. D. Bergelson, A. G. Bukrinskaya, and N. V. Prokazova, "Role of gangliosides in reception of the influenza virus," European Journal of Biochemistry, vol. 128, no. 2-3, pp. 467-474, 1982. 
[34] M. C. Pedroso de Lima, J. Ramalho-Santos, D. Flasher, V. A. Slepushkin, S. Nir, and N. Duzgunes, "Target cell membrane sialic acid modulates both binding and fusion activity of influenza virus," Biochimica et Biophysica Acta, vol. 1236, no. 2, pp. 323-330, 1995.

[35] D. C. Wiley and J. J. Skehel, "The structure and function of the hemagglutinin membrane glycoprotein of influenza virus," Annual Review of Biochemistry, vol. 56, pp. 365-394, 1987.

[36] R. G. Spiro and V. D. Bhoyroo, "Structure of the O glycosidically linked carbohydrate units of fetuin," Journal of Biological Chemistry, vol. 249, no. 18, pp. 5704-5717, 1974.

[37] S. Takasaki and A. Kobata, "Asparagine-linked sugar chains of fetuin: occurrence of tetrasialyl triantennary sugar chains containing the Gal $\beta \rightarrow 3 \mathrm{GlcNAc}$ sequence," Biochemistry, vol. 25, no. 19 , pp. 5709-5715, 1986.

[38] Y. Makimura, S. Watanabe, T. Suzuki et al., "Chemoenzymatic synthesis and application of a sialoglycopolymer with a chitosan backbone as a potent inhibitor of human influenza virus hemagglutination," Carbohydrate Research, vol. 341, no. 11, pp. 1803-1808, 2006.

[39] M. N. Matrosovich, L. V. Mochalova, V. P. Marinina, N. E. Byramova, and N. V. Bovin, "Synthetic polymeric sialoside inhibitors of influenza virus receptor-binding activity," FEBS Letters, vol. 272, no. 1-2, pp. 209-212, 1990.

[40] M. Ogata, T. Murata, K. Murakami et al., "Chemoenzymatic synthesis of artificial glycopolypeptides containing multivalent sialyloligosaccharides with a $\gamma$-polyglutamic acid backbone and their effect on inhibition of infection by influenza viruses," Bioorganic and Medicinal Chemistry, vol. 15, no. 3, pp. 1383-1393, 2007.

[41] A. Tsuchida, K. Kobayashi, N. Matsubara, T. Muramatsu, T. Suzuki, and Y. Suzuki, "Simple synthesis of sialyllactosecarrying polystyrene and its binding with influenza virus," Glycoconjugate Journal, vol. 15, no. 11, pp. 1047-1054, 1998.

[42] M. Tkáčová, E. Varečková, I. C. Baker, J. M. Love, and T. Ziegler, "Evaluation of monoclonal antibodies for subtyping of currently circulating human type A influenza viruses," Journal of Clinical Microbiology, vol. 35, no. 5, pp. 1196-1198, 1997.

[43] E. Varečková, V. Mucha, F. Kostolanský, L. V. Gubareva, and A. Klimov, "HA2-specific monoclonal antibodies as tools for differential recognition of influenza A virus antigenic subtypes," Virus Research, vol. 132, no. 1-2, pp. 181-186, 2008.

[44] E. Varečková, V. Mucha, S. A. Wharton, and F. Kostolanský, "Inhibition of fusion activity of influenza A haemagglutinin mediated by HA2-specific monoclonal antibodies," Archives of Virology, vol. 148, no. 3, pp. 469-486, 2003.

[45] F. Kostolansky, B. Styk, and G. Russ, "Inhibition of influenza virus haemolytic and haemagglutination activities by monoclonal antibodies to haemagglutinin glycopolypeptides HA1 and HA2," Acta Virologica, vol. 33, no. 6, pp. 504-512, 1989.

[46] T. D. Butters, R. C. Hughes, and P. Vischer, "Steps in the biosynthesis of mosquito cell membrane glycoproteins and the effects of tunicamycin," Biochimica et Biophysica Acta, vol. 640, no. 3, pp. 655-671, 1981.

[47] A. D. Hooker, N. H. Green, A. J. Baines et al., "Constraints on the transport and glycosylation of recombinant IFN- $\gamma$ in Chinese hamster ovary and insect cells," Biotechnology and Bioengineering, vol. 63, no. 5, pp. 559-572, 1999.

[48] V. Stollar, B. D. Stollar, and R. Koo, "Sialic acid contents of Sindbis virus from vertebrate and mosquito cells. Equivalence of biological and immunological viral properties," Virology, vol. 69, no. 1, pp. 104-115, 1976.
[49] N. Tomiya, E. Ailor, S. M. Lawrence, M. J. Betenbaugh, and Y. C. Lee, "Determination of nucleotides and sugar nucleotides involved in protein glycosylation by high-performance anionexchange chromatography: sugar nucleotide contents in cultured insect cells and mammalian cells," Analytical Biochemistry, vol. 293, no. 1, pp. 129-137, 2001.

[50] K. Shinya, Y. Fujii, H. Ito, T. Ito, and Y. Kawaoka, "Characterization of a neuraminidase-deficient influenza a virus as a potential gene delivery vector and a live vaccine," Journal of Virology, vol. 78, no. 6, pp. 3083-3088, 2004.

[51] K. Kuroda, H. Geyer, R. Geyer, W. Doerfler, and H. D. Klenk, "Theoligosaccharides of influenza virus hemagglutinin expressed in insect cells by a baculovirus vector," Virology, vol. 174, no. 2, pp. 418-429, 1990.

[52] C. C. Wang, J. R. Chen, Y. C. Tseng et al., "Glycans on influenza hemagglutinin affect receptor binding and immune response," Proceedings of the National Academy of Sciences of the United States of America, vol. 106, no. 43, pp. 18137-18142, 2009.

[53] K. Kuroda, M. Veit, and H. D. Klenk, "Retarded processing of influenza virus hemagglutinin in insect cells," Virology, vol. 180, no. 1, pp. 159-165, 1991.

[54] L. F. Cassidy, D. S. Lyles, and J. S. Abramson, "Depression of polymorphonuclear leukocyte functions by purified influenza virus hemagglutinin and sialic acid-binding lectins," Journal of Immunology, vol. 142, no. 12, pp. 4401-4406, 1989.

[55] U. Haupts, S. Maiti, P. Schwille, and W. W. Webb, "Dynamics of fluorescence fluctuations in green fluorescent protein observed by fluorescence correlation spectroscopy," Proceedings of the National Academy of Sciences of the United States of America, vol. 95, no. 23, pp. 13573-13578, 1998.

[56] M. Kneen, J. Farinas, Y. Li, and A. S. Verkman, "Green fluorescent protein as a noninvasive intracellular $\mathrm{pH}$ indicator," Biophysical Journal, vol. 74, no. 3, pp. 1591-1599, 1998. 

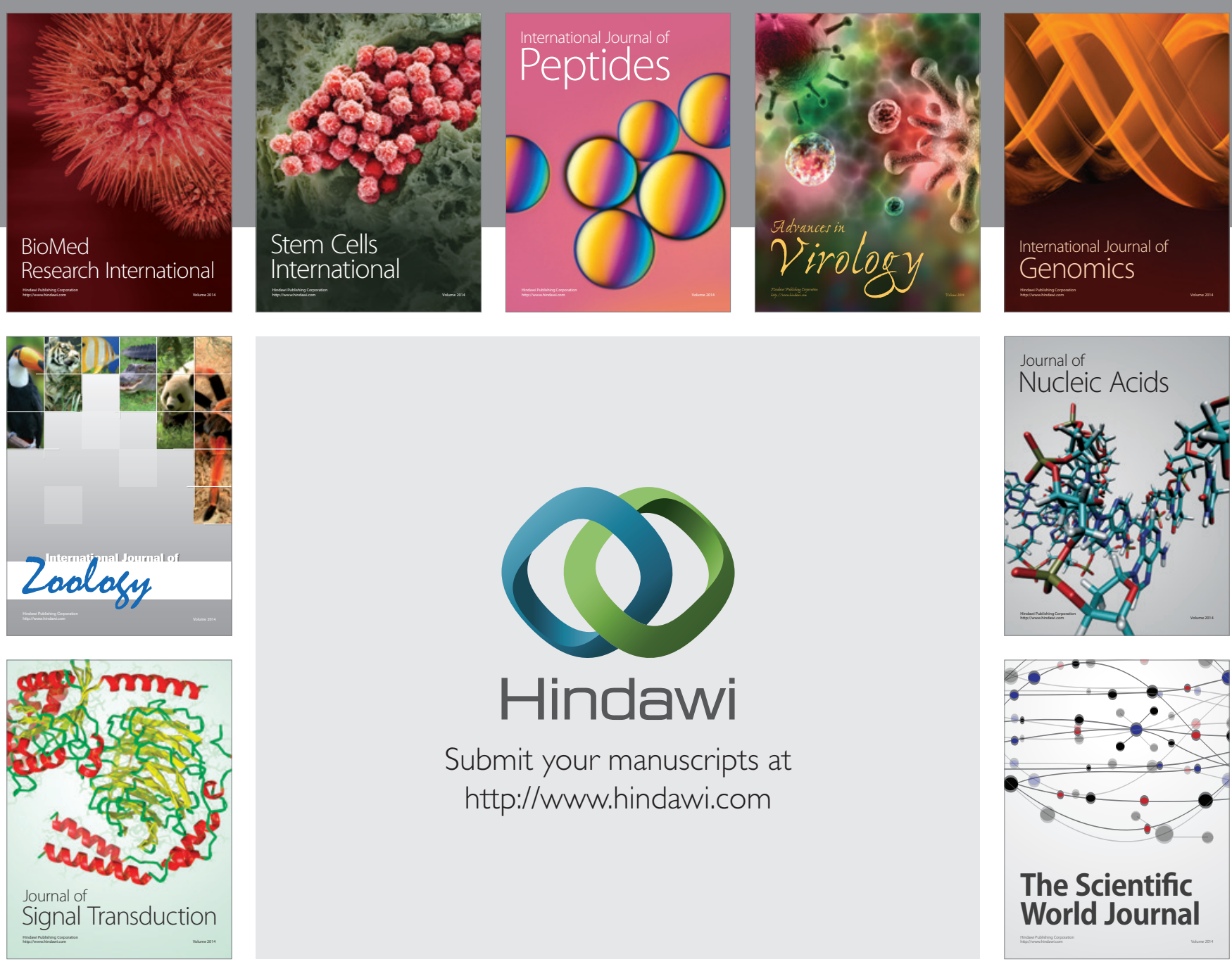

Submit your manuscripts at

http://www.hindawi.com
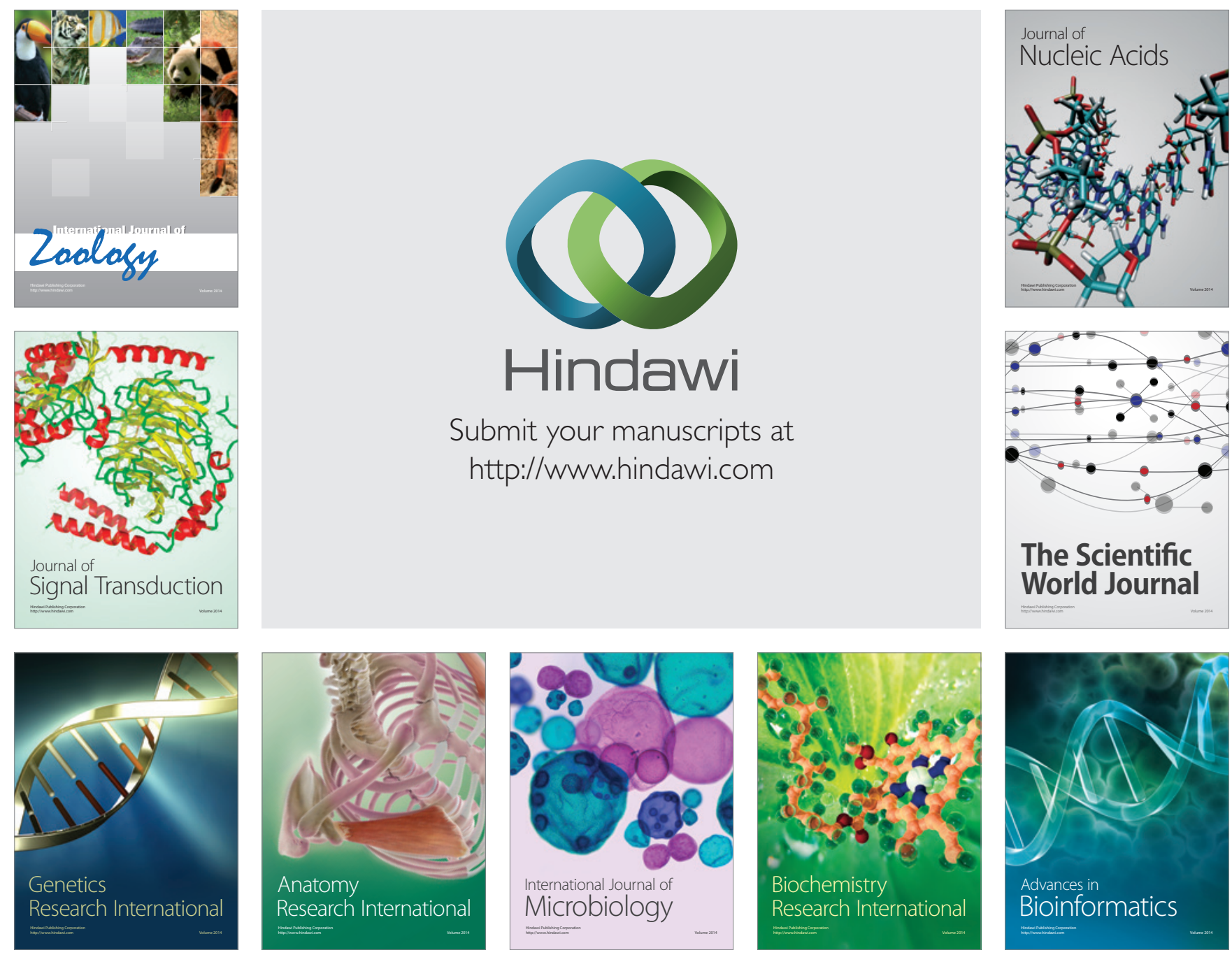

The Scientific World Journal
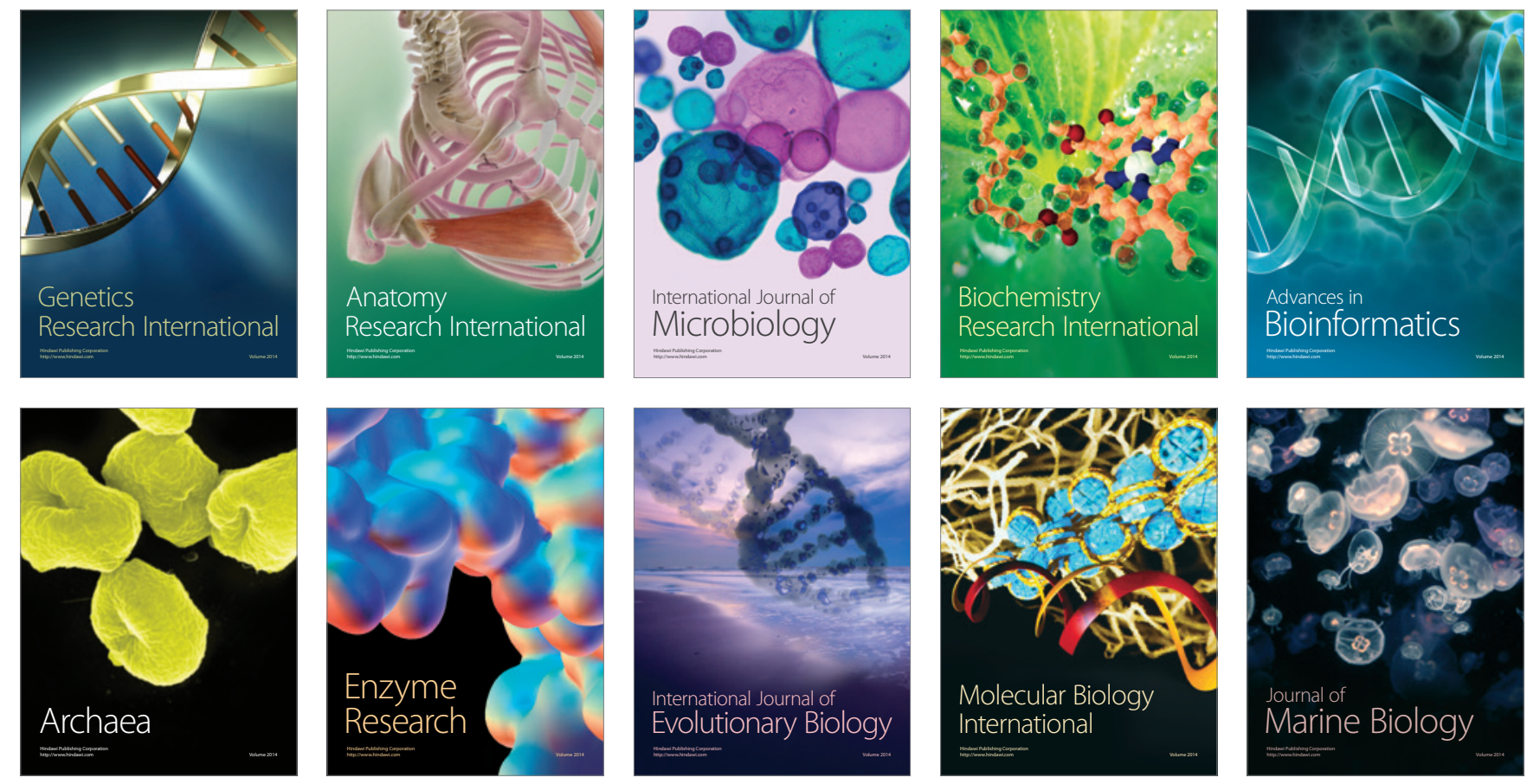